\title{
Effect of composts, nitrogen salts and NPK fertilizers on methane oxidation potential at different temperatures
}

\section{Louis-B. Jugnia ${ }^{1 \dagger}$, Yaseen Mottiar ${ }^{1}$, Euphrasie Djuikom ${ }^{2}$, Alexandre R. Cabral $^{3}$ and} Charles W. Greer ${ }^{1}$

${ }^{1}$ National Research Council Canada, Biotechnology Research Institute, 6100 Royalmount Avenue, Montreal, Quebec, Canada, H4P 2R2

${ }^{2}$ University of Douala, Faculty of Sciences, P.O.Box: 24157 Douala, Cameroon ${ }^{3}$ Department of Civil Engineering, Université de Sherbrooke, 2500 boulevard de l'Université, Sherbrooke, Quebec, Canada, J1K 2R1

Running title: Effects of compost, nitrogen salts and fertilizers on methanotrophic activity

Jugnia, L-B. \#, Mottiar, Y., Djuikom, E., Cabral, A.R., and Greer, C.W. (2012). Effect of compost, nitrogen salts and NPK fertilizers on methane oxidation potential at different temperatures. Applied Microbiology and biotechnology, 93: 2633-2643. DOI 10.1007/s00253-011-3560-4

Keywords: Methanotrophs, potential activity, compost, nitrogen salts, NPK fertilizers,

\section{$\dagger$ Corresponding author}

Phone: + 1 (514) 496-0714; Fax: + 1 (514) 496-6265

29 Email: louis.jugnia@cnrc-nrc.gc.ca 


\section{Abstract}

32 The effects of compost, nitrogen salts (N-salts) and nitrogen-phosphorous-potassium

33 (NPK) fertilizers on the methane oxidation potential performance (MOP) of a landfill

34 cover soil were assessed under various temperature regimes. For this, batch assays were

35 conducted at 5,15 and $25^{\circ} \mathrm{C}$ with microcosms containing soil slurries amended with

36 different types and amounts of compost, N-salts and NPK fertilizers at different

37 concentrations. Results indicated variable impacts dependent on the type of amendment

38 and the incubation temperature. For a given incubation temperature, MOP varied from

39 one compost to another and with the amount of compost added, except for the

40 shrimp/peat compost. With this latter compost, independent of amount, MOP values

41 remained similar and in general were significantly higher than those obtained with the

42 other composts. N-salts addition indicated lack of inhibition or even stimulation of MOP.

43 MOP with NPK fertilizer additions were amongst the highest of this study, the minimum

44 value obtained with NPK (20-0-20) suggested, among others, the significance of P

45 element for methanotrophs. MOP generally increased with temperature, with an

46 indication that at high temperatures nutrients were no longer the major factor regulating

47 methanotrophic activity. Overall, at each of the three temperatures tested, MOP with

48 NPK fertilizer amendments provided the best results and were comparable to those

49 observed with the addition of the shrimp/peat compost. Results of this study provide the

50 first evidence on: 1) that compost addition to improve methanotrophic activity in a

51 landfill cover soil requires considerations on the amounts and/or type of compost used, 2)

52 the importance of using NPK fertilizers rather that N-salts, in enhancing this activity 
53 principally at low temperatures with potentially beneficial impact for the vegetation

54 growth that is an advantage on this type of soil.

55

56 
59 effectively than $\mathrm{CO}_{2}$ and has a global warming potential 25 times higher than that of $\mathrm{CO}_{2}$

60 (IPCC 2007). Methane is the product of the anaerobic degradation of organic matter by

61 methanogenic Archeae (Zinder 1993). Landfills represent a significant source of

62 anthropogenic $\mathrm{CH}_{4}$ emissions contributing as much as $17 \%$ (Wuebbles and Hayhoe 2002)

63 of the $70 \%$ of $\mathrm{CH}_{4}$ emissions attributed to human activities (IPCC 2007).

64 Landfills may play an important role in climate scenarios, as a source of $\mathrm{CH}_{4}$.

65 When a landfill site is full and capped with soil, vertical migration brings $\mathrm{CH}_{4}$ produced

66 by methanogenic bacteria deep within the anaerobic region of the landfill, to the aerobic

67 environment near the surface, where it may be subjected to microbiological oxidation by

68 methane-oxidizing bacteria (methanotrophs) (Whalen et al. 1990; Jones and Nedwell

69 1993; Humer and Lechner 2001). Methane emissions from landfills can be mitigated by

70 microbial methane oxidation in landfill cover soils (Boeckx et al. 1996; Hilger and

71 Humer 2003; Kallistova et al. 2005) - known as biocovers. Several previous

72 investigations have assessed the role of compost as biofilters in landfills cover soils

73 (Humer and Lechner 1999; Straska et al. 1999; Wilshusen et al. 2004).

74 Composted organics are thought to promote good microbial growth by improving

75 the porosity, water holding capacity, $\mathrm{pH}$, and nutrient supply (Hilger and Humer 2003).

76 Accordingly, there is an increasing use of compost in biocovers and biofilters to mitigate

77 methane emissions from landfills and recent investigations in this direction have shown

78 promising results (Humer and Lechner 2001; Barlaz et al. 2004; Maurice and Lagerkvist

79 2004; Wilshusen et al. 2004; Kettunen et al. 2006; Powelson et al. 2006; Jugnia et al. 
80 2008; Aït-Benichou et al. 2009). Organic amendments to soil generally result in an

81 increase in enzymatic activity (Bandick and Dick 1999; Garcia-Gil et al. 2000; Perucci et

82 al. 2000). Also, Saison et al. (2006) reported that compost amendment affects the overall

83 activity of the soil microbial community.

84 Soil-mediated $\mathrm{CH}_{4}$ oxidation provides an important biological sink for both

85 atmospheric and for in situ produced $\mathrm{CH}_{4}$ (Amaral et al. 1998). Compost amendment to

86 soil is a common practice generally used to improve soil fertility and physical structure.

87 Numerous types of compost exist for this use and the amount applied varied from one site

88 to site. However, the specific impact of compost amendments on methanotrophic

89 capacity of soil is not well known and should be investigated insofar as, among other

90 impacts, excessive use of organic amendment is likely to intensify non methanotrophic

91 microbial activity, thus limiting the soil's $\mathrm{CH}_{4}$ oxidation capacity.

92 The present study examined the combined effects of temperature and amendments

93 of different types and amounts of compost on the $\mathrm{CH}_{4}$ oxidizing potential of a soil, given

94 that compost is increasingly used in landfill cover soil. For this, samples from a landfill

95 cover soil that housed a well established community of methanotrophs (Aït-Benichou et

96 al. 2009) was chosen. To our knowledge no previous work has compared the rates of $\mathrm{CH}_{4}$

97 oxidation potential of a landfill cover soil amended with different types and amounts of

98 compost under various temperature regimes. Similarly, we examined the effects of

99 nitrogen salts and nitrogen-phosphorous-potassium fertilizers. Understanding changes in

100 methanotrophic activity induced by these treatments is of economic and environmental

101 importance to optimize the mitigation of the net flux of $\mathrm{CH}_{4}$ from landfills. 


\section{Material and methods}

104 Samples, soil slurries and $\mathrm{CH}_{4}$ oxidation potential

105 Landfill cover soil samples were collected at the surface from an existing landfill

106 located at Saint-Nicéphore, Quebec (Canada) and sieved to $2 \mathrm{~mm}$. This soil had been

107 exposed to methane and its granulometric composition was: $25.2 \%$ sand, $67.3 \%$ silt and

$1087.5 \%$ clay. Five different types of compost (green waste, biosolid waste, pulp and paper

109 residue, manure and shrimp/peat) were obtained from a local producer (Les Composts du

110 Québec) and sieved to $2 \mathrm{~mm}$. Subsamples of soil and compost were sterilized by gamma

111 irradiation at MDS Nordiom in Laval, Quebec (Canada). Sterilized and non-sterilized

112 samples were stored in the dark at $4^{\circ} \mathrm{C}$ until use. Physico-chemical properties of this

113 landfill cover soil together with those of the different types of composts that were used 114 are presented in Table 1.

115 Microcosm experiments for the determination of $\mathrm{CH}_{4}$ oxidation potential were 116 performed with soils slurries in aerobic 120 -ml glass serum bottles. Ten $\mathrm{g}$ of sample was 117 used and three amounts $(5,10$ and $25 \%)$ of compost amendment were tested. For this, 7.5 $118 \mathrm{~g}$ of non-sterilized landfill cover soil was amended with either $0 \mathrm{~g}, 0.5 \mathrm{~g}, 1 \mathrm{~g}$, or $2.5 \mathrm{~g}$ of

119 sterile compost: sterilized landfill cover soil was used to bring the final weight to $10 \mathrm{~g}$.

120 Microcosm slurries were prepared by mixing $10 \mathrm{~g}$ of soil (control) or soil/compost

121 mixture with $10 \mathrm{ml}$ of deionized water. For experiments with nitrogen salts and nitrogen122 phosphorous-potassium (NPK) fertilizers, stock solutions of $\mathrm{NH}_{4} \mathrm{Cl},\left(\mathrm{NH}_{4}\right)_{2} \mathrm{SO}_{4}$,

$123 \mathrm{NH}_{4} \mathrm{NO}_{3}, \mathrm{NaNO}_{3}$, urea and NPK at rates of 20-20-20, 20-6-20 and 20-0-20 were prepared

124 so that, the addition of $10 \mathrm{ml}$ of either one of these solutions to $10 \mathrm{~g}$ of soil (7.5 $\mathrm{g}$ of non-

125 sterilized landfill cover soil $+2.5 \mathrm{~g}$ of sterilized landfill cover soil), yielded $600 \mu \mathrm{g}$ of 
126 total nitrogen added in the microcosm. Ten $\mathrm{ml}$ of liquid was enough to form a slurry and

127 thereby minimize variation in $\mathrm{CH}_{4}$ oxidation potential caused by soil moisture.

128 The glass serum bottles were capped with Teflon-lined rubber stoppers and sealed

129 with aluminum crimps. Pure $\mathrm{CH}_{4}(0.5 \mathrm{ml})$ was added to each bottle (equivalent to

130 approximately $5 \% \mathrm{~V} / \mathrm{V}$ ) after withdrawal of an equal volume of the gas phase. All

131 treatments were prepared in triplicate for each incubation temperature $\left(5^{\circ} \mathrm{C}, 10^{\circ} \mathrm{C}\right.$ or

$13225^{\circ} \mathrm{C}$ ). The $\mathrm{CH}_{4}$ oxidation potential (MOP) was evaluated by measuring the headspace

133 concentration of $\mathrm{CH}_{4}$ over the course of the incubation period. Measurements were

134 performed by gas chromatography on a SRI $8610 \mathrm{C}$ gas chromatograph (SRI, Torrance,

135 CA, USA) equipped as described in Roy and Greer (2000). For gas determinations, 0.2

$136 \mathrm{ml}$ of the headspace gas was injected into the GC system with simultaneous integration of

137 peaks using the Peak Simple II software (SRI, Torrance, CA, USA).

\section{Statistics}

139 A well-adjusted linear regression equation describing the $\mathrm{CH}_{4}$ oxidation in our 140 microcosm was obtained independently with measurements taken using repeated 141 sampling in the same triplicate microcosms through the analyzed period. Potential $\mathrm{CH}_{4}$ 142 oxidation rates were determined from the slope of the regression. For statistical analysis, 143 general linear model with unbalanced repeated measures (type III) analysis was applied 144 using the PASW statistics 18 package (formerly SPSS Statistics). The predicted means 145 from the general linear model were compared by using the least significant difference 146 method where a $\mathrm{P}$ value of $<0.05$ was considered to be significant.

\section{Results}




\section{Characteristics of the landfill cover soil and the different composts}

150 Results of physico-chemical analysis of the landfill cover soil and the different

151 composts are presented in Table 1 . The $\mathrm{pH}$ of the landfill cover soil was alkaline and the

152 different composts were neutral or slightly alkaline. The concentration of total nitrogen

153 and phosphorus in the soil from the landfill cover differed considerably from those of the

154 composts. This was also valid for bacterial assimilable forms of these chemicals $\left(\mathrm{NH}_{4}^{+}\right.$,

$155 \mathrm{NO}_{2}-\mathrm{NO}_{3}$ and $\mathrm{PO}_{4}{ }^{3-}$ ) that represented only a minor fraction of the total concentration

156 available. Indeed, $\mathrm{NH}_{4}^{+}$concentrations were generally $<5 \mathrm{mg}$ of $\mathrm{N} \mathrm{kg}^{-1}$ DWsoil (i.e. 0 to 0.2

$157 \%$ of total nitrogen) and lower than the $\mathrm{NO}_{2}-\mathrm{NO}_{3}$ concentration representing 0.2 to 1.86

$158 \%$ of total nitrogen, if one excludes the shrimp/peat compost with $4.5 \%$ of total nitrogen.

159 With $\mathrm{PO}_{4}{ }^{3-}$, concentrations were $<5 \mathrm{mg}$ of $\mathrm{P} \mathrm{kg}^{-1}$ DWsoil except for the manure compost

160 that contained the highest concentration ( $848 \mathrm{mg}$ of $\mathrm{P} \mathrm{kg}^{-1}$ DWsoil, i.e. $8.23 \%$ of total $\mathrm{P}$ ).

161 Effect of compost types and amount on potential $\mathrm{CH}_{4}$ oxidation performance at

162 different temperatures

163 Of the different types of compost considered, $\mathrm{CH}_{4}$ consumption was faster with

164 samples amended with shrimp/peat compost, irrespective of the amount of this compost

165 added to the soil sample, with the complete oxidation of $\mathrm{CH}_{4}$ in microcosms lasting: 4

166 days at $25^{\circ} \mathrm{C}$, between 7 and 12 days at $15^{\circ} \mathrm{C}$, and $<30$ days at $5^{\circ} \mathrm{C}$ (Fig. 1). This was not

167 the case with the other composts for which, the complete oxidation of $\mathrm{CH}_{4}$ required 6 to 8

168 days at $25^{\circ} \mathrm{C}$, increasing to 21 to 30 days at $15^{\circ} \mathrm{C}$ or $\geq 30$ days at $5^{\circ} \mathrm{C}$ (Fig. 1).

169 Nevertheless, samples amended with biosolid waste and manure compost exhibited

170 activities that were a bit faster and more considerable at 5 and $15^{\circ} \mathrm{C}$ with the increasing in

171 the ratio of these composts in soil samples (Fig. 1). 
172 Overall, the concentration versus time profiles of all the experiments in Fig. 1

173 indicated an impact of the amount of compost on $\mathrm{CH}_{4}$ oxidation: at low temperatures,

174 there was an increasing variability among the different composts dependent on the

175 amount of compost added. Samples amended with shrimp/peat compost exhibited the

176 highest MOP, with average values of $0.7,2.0$ and $5.7 \mu \mathrm{gCH}_{4} \cdot \mathrm{g}^{-1} \mathrm{DWsoil} \cdot \mathrm{h}^{-1}$ at 5,10 and

$17725^{\circ} \mathrm{C}$, respectively. When excluding these values, the lowest MOP, achieved with $1.5 \%$

178 compost, was between $0.24 \mu \mathrm{gCH} 4 . \mathrm{g}^{-1}$ DWsoil. $\mathrm{h}^{-1}$ at $5^{\circ} \mathrm{C}$ and $2.45 \mu \mathrm{gCH} 4 . \mathrm{g}^{-1}$ Dwsoil. $\mathrm{h}^{-1}$ at $25^{\circ} \mathrm{C}$

179 (Fig. 2). These values increased considerably with 25\% compost and fluctuated between

$180 \quad 0.32 \mu \mathrm{gCH} 4 . \mathrm{g}^{-1} \mathrm{DW}_{\text {soil. }} \mathrm{h}^{-1}$ at $5^{\circ} \mathrm{C}$ and $4.03 \mu \mathrm{gCH} 4 . \mathrm{g}^{-1}$ DWsoil. $\mathrm{h}^{-1}$ at $25^{\circ} \mathrm{C}$ (Fig. 2).

181 Effect of nitrogen salts and NPK fetilizers on potential $\mathrm{CH}_{4}$ oxidation performance

182 at different temperatures

$183 \mathrm{CH}_{4}$ consumption was also improved when soils were amended with nitrogen salts or

184 NPK fertilizers, although this was lower with urea and NPK. (20-0-20). With different

185 nitrogen salts, the profiles of $\mathrm{CH}_{4}$ consumption over time were close to each other on a

186 time scale of $<5$ days (at $25^{\circ} \mathrm{C}$ ), to 63 to 80 days (at $15^{\circ} \mathrm{C}$ ) or $>80$ days (at $5^{\circ} \mathrm{C}$ ) (Fig. 3 ).

187 With fertilizers, NPK (20-20-20) and NPK (20-6-20) exhibited similar profiles of $\mathrm{CH}_{4}$

188 consumption over time, with oxidation completed within 21 to 42 days at 15 and $5^{\circ} \mathrm{C}$,

189 while NPK (20-0-20) was $>79$ days at 15 and $5^{\circ} \mathrm{C}$ (Fig. 3). For nitrogen salts and

190 fertilizers, the time elapsed for complete $\mathrm{CH}_{4}$ consumption increased with decreasing

191 incubation temperature (Fig. 3), a trend that was observed with compost addition.

192 At a given temperature, changes in MOP were less significant between the different

193 N-salts than the NPK fertilizers tested, but became more important with shifts in

194 temperature, notably between 15 and $25^{\circ} \mathrm{C}$ (Fig. 4). Methane uptake rates ranged from 
1950.20 to $0.70 \mu \mathrm{gCH}_{4} \cdot \mathrm{g}^{-1} \mathrm{DW}$ soil. $\mathrm{h}^{-1}$ at $5^{\circ} \mathrm{C}$, fluctuated between 0.31 and $0.97 \mu \mathrm{gCH}_{4} \cdot \mathrm{g}^{-}$

$196{ }^{1}{ }_{\text {DWsoil. }} \mathrm{h}^{-1}$ at $15^{\circ} \mathrm{C}$, and increased significantly to 2.35 to $7.18 \mu \mathrm{gCH} 4 . \mathrm{g}^{-1} \mathrm{DWsoil} \cdot \mathrm{h}^{-1}$ at $25^{\circ} \mathrm{C}$

197 (Fig. 4). Except for urea, methane uptake rates at $25^{\circ} \mathrm{C}$ were similar for NPK fertilizers

198 and the N-salts tested (Fig. 4). This was not the case at 5 and $15^{\circ} \mathrm{C}$, since with NPK the

199 MOP were greater than those obtained with $\mathrm{N}$-salts: the maximum values $\left(0.40 \mu \mathrm{gCH}_{4} \cdot \mathrm{g}^{-}\right.$

$\left.200{ }^{1}{ }_{\text {DWsoil }} \cdot \mathrm{h}^{-1}\right)$ obtained with $\mathrm{N}$-salts was similar to the minimum value $\left(0.30 \mu \mathrm{gCH}_{4} \cdot \mathrm{g}^{-}\right.$

$201{ }^{1}{ }_{\text {DWsoil. }}{ }^{-1}$ ) observed with NPK (20-0-20) (Fig. 4).

202 Under optimum conditions at $25^{\circ} \mathrm{C}, \mathrm{CH}_{4}$ oxidation with NPK fertilizers provided the 203 best results, comparable to those observed with the shrimp/peat compost. They were

204 followed in decreasing order by nitrogen salts and other types of compost. At 5 and $15^{\circ} \mathrm{C}$,

205 addition of NPK fertilizers provided the best results, and was followed by composts that 206 were better than the nitrogen salts.

207 For almost all the samples, the oxidation rate increased with increasing temperature, 208 especially between 15 and $25^{\circ} \mathrm{C}$ (Figs. 3 and 4). Also for all the samples, the optimum 209 temperature was $25^{\circ} \mathrm{C}$, the highest temperature tested during our investigations.

\section{$211 \quad$ Discussion}

212 The results indicated that $\mathrm{CH}_{4}$ oxidation performance in microcosms was generally 213 improved by amendment with compost, nitrogen salts and NPK fertilizers. These findings

214 are similar to those reported by others for landfill covers soils (Hilger et al. 2000; Humer 215 and Lechner 2001; De Visscher and Van Cleemput 2003; Barlaz et al. 2004; Maurice and 216 Lagerkvist 2004; Aït-Benichou et al. 2009; Albanna and Fernandes 2009; Lee et al. 217 2009). 
218 The $\mathrm{CH}_{4}$ oxidation capacity of landfill cover soils is quite variable. Albanna and 219 Fernandes (2009) reported values of $\mathrm{CH}_{4}$ oxidation capacities of landfill cover soils

220 incubated at 3 different temperatures $\left(5,22\right.$ and $\left.35^{\circ} \mathrm{C}\right)$, ranging from 3.3 to $12.3 \mu \mathrm{g}$

$221 \mathrm{CH}_{4} \cdot \mathrm{g}^{-1}$ DWsoil $\mathrm{h}^{-1}$ with a clayey silt soil, and from 3.5 to $10.5 \mu \mathrm{g} \mathrm{CH}_{4} \mathrm{~g}^{-1}$ DWsoil $\mathrm{h}^{-1}$ with a

222 clay soil. Using engineered soil with a mixture of sewage sludge compost and de-inking

223 waste amended with sand (SDS soil) or bark chips (SDB) incubated at $4-6^{\circ} \mathrm{C}$, Kettunen et 224 al (2006) reported $\mathrm{CH}_{4}$ oxidation rates of 3.75 and $2.45 \mu \mathrm{g} \mathrm{CH} 4 \mathrm{~g}^{-1}$ DWsoil $\mathrm{h}^{-1}$, respectively.

225 Einola et al. (2007) found $\mathrm{CH}_{4}$ consumption rates ranging between 0.48 and $3.68 \mu \mathrm{g} \mathrm{CH} 4$

$226 \mathrm{~g}^{-1}$ DWsoil $\mathrm{h}^{-1}$ for landfill cover soils incubated between 1 and $6^{\circ} \mathrm{C}$. Compared to others, our

227 results fall within the lower range of those previously published for landfill cover soil,

228 probably because we added water in our microcosms to form a slurry and therefore

229 minimize variation caused by soil moisture. Whalen et al. (1990) and Czepiel et al.

230 (1996) confirmed that gas diffusion at soil saturation is limited by the diffusion

231 coefficient of $\mathrm{CH}_{4}$ in water, which is 4 orders of magnitude lower than in the air.

232 Effect of compost type and percentage on potential $\mathrm{CH}_{4}$ oxidation performance

233 The MOP values from our experimental microcosms amended with compost were

234 generally higher than those observed in control microcosms that contained only the

235 landfill cover soil. This is an indication that compost addition to this landfill cover soil

236 provided some required missing factors that fueled the activity of indigenous

237 methanotrophs. Among these factors are organic matter and nutrients. Previous studies

238 established a clear relationship between methanotrophic activity and/or diversity and

239 organic matter concentration (Christophersen et al. 2000; Bin et al. 2009). Our results

240 agree with both field observations at landfills and results from laboratory studies that 
241 have demonstrated that the $\mathrm{CH}_{4}$ oxidation potential in mineral soils can be enhanced by

242 adding organic material, e.g. sewage sludge (Kightley et al. 1995) and compost (Humer

243 and Lechner 2001; Barlaz et al. 2004; Maurice and Lagerkvist 2004; Aït-Benichou et al.

244 2009). Also, Kettunen et al (2006) and Wilshusen (2004) reported that compost should be

245 capable of enhancing the oxidation of $\mathrm{CH}_{4}$ at rates two to three times higher than that of

246 mineral soils.

247 MOP observed within each group of samples treated separately with the same 248 amounts of the different composts under study at a given incubation temperature, varied

249 from one type of compost to another (Fig. 2). This suggests differences between the type

250 of compost that was evaluated, with indices regarding the quantity and quality of the

251 elements in the compost that powered methanotrophic activity. The observed increase in

252 MOP with increasing amounts of compost, except with shrimp/peat compost, is evidence

253 of this quantitative effect. Moona et al. (2010) reached the same conclusion using 254 increasing ratios of earthworm cast to improve methanotrophic activity in a filter bed

255 material consisting of a mixture of earthworm cast and rice paddy soil in a biocover. In

256 contrast, results with shrimp/peat compost tend to highlight the difference among

257 composts in terms of quality. With the shrimp/peat compost and at each of the three

258 temperatures examined, MOP values remained similar despite differences in the amount

259 of this compost added.

260 MOP values obtained with shrimp/peat compost were generally higher than those 261 observed with the other composts. Small differences, principally at 5 and $15^{\circ} \mathrm{C}$, were

262 detected between composts with, in most cases, the highest MOP values attributed to 263 manure and/or biosolid composts. As such, shrimp/peat compost followed by manure and 
264 or biosolid composts could be considered the most effective additives. However, since

265 excessive use of organic amendments is likely to intensify non-methanotrophic microbial

266 activity, thus limiting the soils $\mathrm{CH}_{4}$ oxidation capacity, shrimp/peat could be considered

267 the most effective compost. From this study, the highlighted differences between

268 composts in terms of quality and quantity, in relation to their ability of enhance

269 methanotrophic activity, are pretty new information that had never been reported with

270 landfill cover soil, although previous studies focused on compost types.

271 At all of the three temperatures considered in this study, MOP values with the

272 lowest amount of shrimp/peat compost provided similar results to the highest amounts of

273 other composts. The main physico-chemical property of shrimp/peat compost that

274 differed from the other composts was the relatively high concentration of bioavailable $\mathrm{N}$,

275 in the form of $\mathrm{NO}_{2}-\mathrm{NO}_{3}$. This prompted us to examine how $\mathrm{N}$ elements may impacted

276 MOP in the landfill cover soil under study.

277

Effect of nitrogen salts and NPK fetilizers on potential $\mathrm{CH}_{4}$ oxidation performance

278 As the methanotrophic community developed, the mineral $\mathrm{N}$ content of the soil

279 decreased (De Visscher et al. 1999), and results of other studies reported an increase of

280 methane oxidation rates possibly due to a relief of nitrogen limitation (Hilger et al. 2000;

281 De Visscher and Van Cleemput 2003; Lee et al. 2009). We hypothesized that the impact

282 of $\mathrm{N}$ elements may change with the type of nitrogen salt used, and therefore a range of

283 nitrogen salts were tested together with NPK fertilizers.

284 Our results, in general, indicated that there was a lack of inhibition and even $\mathrm{CH}_{4}$

285 oxidation stimulation, following addition of the different nitrogen salts. This is consistent

286 with previous studies (Bodelier et al. 2000; Hilger et al. 2000; Sitaula et al. 2000; De 
287 Visscher et al. 2001; De Visscher and Van Cleemput 2003), but on the other hand

288 somewhat contrasts with results by Kightley et al. (1995) reporting that $\mathrm{NO}_{3}^{-}$had an

289 inhibitory effect on $\mathrm{CH}_{4}$ oxidation in landfill cover soils. De Visscher (2001) observed

290 that amending the landfill cover soil with nitrifying sludge or compost initially inhibited

291 methane oxidation, followed by a stimulation after a few days. In general, the reported

292 information about methane oxidation in the presence of nitrogen salts is often

293 contradictory (Hütsch et al. 1994; Dunfield et al. 1995; Willison et al. 1995; Delgado and

294 Mosier 1996; Bodelier and Laanbroek 2004). In the present study, exactly which species

295 of the $\mathrm{N}$ salts was the most important in the stimulation of soil mediated $\mathrm{CH}_{4}$ oxidation

296 remained unclear principally at 5 and $10^{\circ} \mathrm{C}$, since at $25^{\circ} \mathrm{C}$ and with the exception of urea,

297 all the $\mathrm{N}$-salts tested similarly increased activity. Urea is a $\mathrm{NH}_{4}{ }^{+}$-producing compound

298 and its inhibitory effect on methanotrophs has been demonstrated (Dubey and Singh

299 2000; Zheng et al. 2008). However, the mechanism responsible for this effect on $\mathrm{CH}_{4}$

300 uptake is complex because it involves both methanotrophs and nitrifiers. Others (Bédard

301 and Knowles 1989) hypothesize that $\mathrm{NH}_{4}^{+}$is a competitive inhibitor of $\mathrm{CH}_{4}$

302 monoxygenase.

303 At 5 and $15^{\circ} \mathrm{C}$, the highest methane uptake rates using $\mathrm{N}$-salts matched the lowest

304 rates observed with NPK fertilizers, suggesting that NPK fertilizers were more efficient

305 than N-salts in improving methanotrophic activity. Although the increase in methane

306 oxidation rates can be due to relief of nitrogen limitation, Zheng et al. (2008) reported

307 that potassium $(\mathrm{K})$ fertilizer may play an important role in maintaining methanotrophic

308 metabolic processes, and a field experiment by Babu et al. (2006) suggested amendment

309 with $\mathrm{K}$ to stimulate the activity of methanotrophic bacterial populations. The fact that the 
310 lowest $\mathrm{CH}_{4}$ uptake rates at 5 and $15^{\circ} \mathrm{C}$ were obtained with NPK (20-0-20) amendment

311 sugests the importance of $\mathrm{P}$ element in the metabolism of the indigenous methanotrophic

312 community. Of interest, methanotrophs rely on intracellular polyphosphate (Trotsenko

313 and Shishkina 1990), which in our case might have been accumulated during growth of

314 methanotrophs of our samples in the landfill cover soil. However, the importance of P

315 appears to be less relevant at $25^{\circ} \mathrm{C}$, given that all forms of the NPK fertilizer addition

316 stimulated $\mathrm{CH}_{4}$ uptake to similar extents. At high temperatures, rather than nutrients

317 limiting methanotrophic activity, other complex processes that occur in the environment

318 at these temperatures (organic matter degradation) contribute to releasing, amongst other

319 components, appropriate nutrients that can sustain methanotrophic activity. This points to

320 the role of temperature in enhancing methanotrophic activity, as substantiated by the fact

321 that differences observed at 5 and $15^{\circ} \mathrm{C}$ following additions of NPK fertilizer and/or N-

322 salts, were not noticeable at $25^{\circ} \mathrm{C}$ except for urea.

$323 \quad$ Effect of temperature on methane oxidation

324 Temperature has a direct impact on biological reactions. The response to temperature

325 of the $\mathrm{CH}_{4}$ consumption rate was similar to that generally observed: $\mathrm{CH}_{4}$ consumption

326 increases with increasing temperature (Czepiel et al. 1996; Christophersen et al. 2000;

327 Gebert et al. 2003; Börjesson et al. 2004; Park et al. 2005; Jugnia et al. 2006; Kettunen et

328 al. 2006; Jugnia et al. 2008). This generally occurs when the $\mathrm{CH}_{4}$ concentration, among

329 other factors, is not limiting (Pawlowska and Stepniewski 2006; Einola et al. 2007). The

330 rate of $\mathrm{CH}_{4}$ consumption by methanotrophs in soil is affected by the rate of substrate

$331\left(\mathrm{CH}_{4}\right.$ and $\left.\mathrm{O}_{2}\right)$ supply as well as the amount and activity of $\mathrm{CH}_{4}$ monooxygenase enzymes

332 that catalyze the process. Accordingly, Boeckx et al. (1996) observed a low response of 
$333 \mathrm{CH}_{4}$ consumption to temperature (average $\mathrm{Q}_{10}$ 1.9) in landfill cover soil incubate at $10 \mu \mathrm{l}$

$3341^{-1} \mathrm{CH}_{4}$ in contrast to the higher $\mathrm{Q}_{10}$ values (1.9-7.26) in previous studies at $>1 \% \mathrm{CH}_{4}$

335 concentrations (Czepiel et al. 1996; Christophersen et al. 2000; De Visscher et al. 2001;

336 Börjesson et al. 2004), as well as in the present study ( $\mathrm{Q}_{10}$ 2.54-3.43). Our observation

337 that at high temperatures nutrients were no longer the major factor regulating

338 methanotrophic activity, is consistent with a recent report by Albanna (2009) that the

339 temperature effect on $\mathrm{CH}_{4}$ oxidation process was so significant that it masked the effect

340 of moisture content and nutrients.

341 Another important finding of this study is our observation that amendment with NPK

342 fertilizers (containing $[\mathrm{P}]>0$ ) improved $\mathrm{CH}_{4}$ oxidation better than $\mathrm{N}$-salts, notably at 5

343 and $15^{\circ} \mathrm{C}$. At the best of our knowledge, the outcome of such a comparison is something

344 that has not been reported so far for landfill cover soil, and this information would be of

345 great interest for an application under cold climates by landfill owners. On the other

346 hand, this has implications for landfill cover soil where it would be possible to provide

347 nutrients to promote growth and maintain the vegetation system. A good vegetation

348 system minimizes erosion by stabilizing the surface of the cover and it contributes to the

349 aeration and moisture control of the soil.

350

351 Acknowledgements:

352 We gratefully acknowleged finantial support of this work by the National Research

353 Council Canada (NRC) through Biotechnogy Research Intitute (BRI). Y.M. was a

354 summer student from University of Ottawa granted by NRC-BRI. E.D. was supported by 
355 the fellowship program "Professeur Invité du sud" from AUF (Agence Universitaire de la 356 francophonie).

357 
358

359 Aït-Benichou, S., Jugnia, L.-B., Greer, C.W. and Cabral, A. (2009) Methanotrophs amd methanotrophic activity in engineered landfill biocovers. Waste Manage 29, 2509-

365 Amaral, J., Ren, T. and Knowles, R. (1998) Atmospheric methane consumption by forest

366 soils and extracted bacteria at different $\mathrm{pH}$ values. Applied and Environmental 367 Microbiology 64, 2397-2402.

368 Babu, Y.J., Nayak, D.R. and Adhya, T.K. (2006) Potassium application reduces methane 369 emission from a flooded field planted to rice. Biol Fertil Soils 42, 532-541.

370 Bandick, A.K. and Dick, R.P. (1999) Field management effects on soil enzyme activities. $371 \quad$ Soil Biol Biochem 31, 1471-1479.

372 Barlaz, M.A., Green, R.B., Chanton, J.P., Goldsmith, C.D. and Hater, G.R. (2004) 373 Evaluation of a biologically active cover for mitigation of landfill gas emissions. 374 Environ Sci Technol 38, 4891-4899.

375 Bédard, C. and Knowles, R. (1989) Physiology, biochemistry, and specific inhibitors of $376 \mathrm{CH}_{4}, \mathrm{NH}_{4}{ }^{+}$, and $\mathrm{CO}$ oxidation by methanotrophs and nitrifiers. Microbiol Rev 53, 68$377 \quad 84$.

378 Bin, L., Monreal, C.M., Tambong, J.T., Miguez, C.B. and Carrasco-Medina, L. (2009) 379 Phylogenetic analysis of methanotrophic communities in cover soils of a landfill in $380 \quad$ Ontario. Can J Microbiol 55, 1103-1112. 
381 Bodelier, P.L.E. and Laanbroek, H.J. (2004) Nitrogen as a regulatory factor of methane $382 \quad$ oxidation in soils and sediments. FEMS Microbiol Ecol 47, 265-277.

383 Bodelier, P.L.E., Roslev, P., Hencke, T. and Frenzel, P. (2000) Stimulation by ammonium384 based fertilizers of methane oxidation in soil around rice roots. Nature 403, 421-424.

385 Boeckx, P. and Van Cleemput, O. (1996) Methane oxidation in a neutral landfill cover soil: 386 influence of moisture content, temperature, and nitrogen-turnover. J Environ Qual 25, $387 \quad 178-183$.

388 Boeckx, P., Van Cleemput, O. and Villaralvo, I. (1996) Methane emission from landfill and 389 the methane oxidizing capacity of its covering soil. Soil Biol Biochem 28, 1397-1405.

390 Börjesson, G., Sundh, I. and Svensson, B.H. (2004) Microbial oxidation of $\mathrm{CH}_{4}$ at different 391 temperatures in landfill cover soils. FEMS Microbiol Ecol 48, 305-312.

392 Christophersen, M., Linderod, L., Jensen, P.E. and Kjeldsen, P. (2000) Methane oxidation 393 at low temperatures in soil exposed to landfill gas. J Environ Qual 29, 1989-1997.

394 Czepiel, P.M., Mosher, B., Crill, P.M. and Harriss, R.C. (1996) Quantifying the effects of 395 oxidation on landfill methane emissions. Journal of Geophysical Research 101, $396 \quad 16721-16729$.

397 De Visscher, A., Schippers, M. and Van Cleemput, O. (2001) Short-term kinetic response 398 of enhanced methane oxidation in landfill cover soils to environmental factors. Biol $399 \quad$ Fertil Soils 33, 231-237.

400 De Visscher, A. and Van Cleemput, O. (2003) Induction of enhanced $\mathrm{CH}_{4}$ oxidation in $401 \quad$ soils: $\mathrm{NH}_{4}{ }^{+}$inhibition patterns. Soil Biol Biochem 35, 907-913.

402 De Visscher, D., Boeckx, T.P. and Van Cleemput, O. (1999) Methane oxidation in 403 simulated landfill cover soil environments. Environ Sci Technol 33, 1854-1859. 
404 Delgado, J.A. and Mosier, A.R. (1996) Mitigation alternatives to decrease nitrous oxide 405 emissions and urea-nitrogen loss and their effect on methane flux. $J$ Envir Quality 25, $406 \quad 1105-1111$.

407 Dubey, S.K. and Singh, J.S. (2000) Spatio-temporal variation and effect of urea 408 fertilization on methanotrophs in a tropical dryland rice field. Soil Biol Biochem 32, $409 \quad 521-526$

410 Dunfield, P.F., Topp, E., Archambault, C. and Knowles, R. (1995) Effect of nitrogen 411 frtilizers and moisture content on $\mathrm{CH}_{4}$ fluxes in a humisol: Measurements in the field 412 and intact soil cores. Biogeochemistry 29, 199-222.

413 Einola, J.-K.M., Kettunena, R.H. and Rintala, J.A. (2007) Responses of methane oxidation 414 to temperature and water content in cover soil of a boreal landfill. Soil Biology \& $415 \quad$ Biochemistry 39, 1156-1164.

416 Garcia-Gil, J.C., Plaza, C., Soler-Rovira, P. and Polo, A. (2000) Long-term effects of 417 municipal solid waste compost application on soil enzyme activities and microbial 418 biomass. Soil Biol Biochem 32, 1907-1913.

419 Gebert, J., Gröngröft, A. and Miehlich, G. (2003) Kinetics of microbial landfill methane $420 \quad$ oxidation in biofilters. Waste Manage 23, 609-619.

421 Hilger, H. and Humer, M. (2003) Biotic landfill cover treatments for mitigating methane 422 emissions. Environ Monit Assess 84, 71-84.

423 Hilger, H.A., Barlaz, M.A. and Wollum, A.G. (2000) Landfill methane oxidation response 424 to vegetation, fertilization, and liming. J Envir Quality 29, 324-334. 
425 Humer, M. and Lechner, P. (1999) Methane oxidation in compost cover layers of landfills.

426 In Proceeding of the Sardinia 99, 7th International Waste Management and Landfill

427 Symposium. Cagliari, Italy.

428 Humer, M. and Lechner, P. (2001) Microbial methane oxidation for the reduction of 429 landfill gas emissions. Journal of Solid Waste Technology and Management 27, 146$430 \quad 151$.

431 Hütsch, B.W., Webster, C.P. and Powlson, D.S. (1994) Methane oxidation in soil as 432 affected by land-use, soil-pH and N-fertilization. Soil Biology \& Biochemistry 26, $433 \quad 1613-1622$.

434 IPCC. (2007) Climate Change 2007: The Physical Science Basis. Cambridge, United 435 Kingdom: Cambridge University Press.

436 Jones, H.A. and Nedwell, D.B. (1993) Methane emission and methane oxidation in landfill $437 \quad$ cover soil. FEMS Microbiol Ecol 102, 185-195.

438 Jugnia, L.-B., Cabral, A.R. and Greer, C.W. (2008) Biotic methane oxidation within an 439 instrumented experimental landfill cover. Ecol Eng 33, 102-109.

440 Jugnia, L.B., Roy, R., Pacheco-Oliver, M., Planas, D., Miguez, C.B. and Greer, C.W. 441 (2006) Potential activity and diversity of methanotrophs in forest soil, peat, and 442 sediments from hydro-electric reservoir (Robert Bourassa) and lakes in the Canadian $443 \quad$ taiga. Soil Science 171, 127-137.

444 Kallistova, A.Y., Kevbrina, M.V., Nekrasova, V.K., Glagolev, M.V., Serebryanaya, M.I. 445 and Nozhevnikova, A.N. (2005) Methane oxidation in landfill cover soil. 446 Microbiology 74, 608-614. 
447 Kettunen, R.H., Einola, J.-K.M. and Rintala, J.A. (2006) Landfill methane oxidation in $448 \quad$ engineered soil columns at low temperature. Water, Air \& Soil Pollution 177, 313449334.

450 Kightley, D., Nedwell, D.B. and Cooper, M. (1995) Capacity for methane oxidation in 451 landfill cover soils measured in laboratory-scale soil microcosms. Appl Environ $452 \quad$ Microbiol 61, 592-601.

453 Lee, S.-W., Im, J., Dispirito, A.A., Bodrossy, L., Barcelona, M.J. and Semrau, J.D. (2009) 454 Effect of nutrient and selective inhibitor amendments on methane oxidation, nitrous 455 oxide production, and key gene presence and expression in landfill cover soils: 456 Characterization of the role of methanotrophs, nitrifiers, and denitrifiers Appl $457 \quad$ Microbiol Biotechnol 85, 389-403

458 Maurice, C. and Lagerkvist, A. (2004) Assessment of methane oxidation capacity of soil. $459 \quad$ Waste Manage Res 22, 42-48.

460 Moona, K.-E., Lee, S.-Y., Lee, S.H., Ryu, H.W. and Cho, K.-S. (2010) Earthworm cast as a 461 promising filter bed material and its methanotrophic contribution to methane removal $462 \quad J$ Hazard Mater 176, 131-138

463 Park, J.R., Moon, S., Ahn, Y.M., Kim, J.Y. and Nam, K. (2005) Determination of 464 environmental factors influencing methane oxidation in a sandy landfill cover soil. 465 Environmental Technology 26, 93-102.

466 Pawlowska, M. and Stepniewski, W. (2006) An influence of methane concentration on the 467 methanotrophic activity of a model landfill cover. Ecol Eng 2 6, 392-395. 
468 Perucci, P., Dumontet, S., Bufo, S.A., Mazzatura, A. and Casuci, C. (2000) Effects of 469 organic amendment and herbicide treatment on soil microbial biomass. Biol Fertil $470 \quad$ Soil 32, 17-23.

471 Powelson, D.K., Chanton, J., Abichou, T. and Morales, J. (2006) Methane oxidation in $472 \quad$ water-spreading and compost biofilters. Waste Manage Res 24, 528-536.

473 Roy, R. and Greer, C.W. (2000) Hexadecane mineralization and denitrification in two 474 diesel fuel-contaminated soils. FEMS Microbiol Ecol 32, 17-23.

475 Saison, C., Degrange, V., Oliver, R., Millard, P., Commeaux, C., Montange, D. and Le

476 Roux, X. (2006) Alteration and resilience of the soil microbial community following 477 compost amendment: Effects of compost level and compost-borne microbial $478 \quad$ community. Env Microbiol 8, 247-257.

479 Sitaula, B.K., Hansen, S., Sitaula, J.I.B. and Bakken, L.R. (2000) Methane oxidation 480 potentials and fluxes in agricultural soil: effects of fertilisation and soil compaction. $481 \quad$ Biogeochemistry 48, 323-339.

482 Straska, F., Crha, J., Musilova, M. and Kuncarova, M. (1999) LFG-biofilters on old 483 landfills. In Proceeding of the Sardinia 99, 7th International Waste Management and $484 \quad$ Landfill Symposium. Cagliari, Italy.

485 Trotsenko, Y.A. and Shishkina, V.N. (1990) Studies on phosphate metabolism in obligate 486 methanotrophs. FEMS Microbiol Rev 87, 267-272.

487 Whalen, S.C., Reeburgh, W.S. and Sandbeck, K.A. (1990) Rapid methane oxidation in a $488 \quad$ landfill cover soil. Appl Environ Microbiol 56, 3405-3411. 
489 Willison, T.W., Webster, C.P., Goulding, K.W.T. and Powlson, D.S. (1995) Methane 490 oxidation in temperate soils-effects of land-use and the chemical form of nitrogen491 fertilizer. Chemosphere 30, 539-546.

492 Wilshusen, J.P., Hettiaratchi, J.P.A. and Stein, V.B. (2004) Long-term behavior of 493 passively aerated compost methanotrophic biofilter columns. Waste Manage 24, 643$494 \quad 653$.

495 Wuebbles, D.J. and Hayhoe, K. (2002) Atmospheric methane and global change. Earth$496 \quad$ Science Reviews 57, 177-210.1

497 Zheng, Y., Zhang, L.M., Zheng, Y.M., Di, H. and He, J.Z. (2008) Abundance and 498 community composition of methanotrophs in a Chinese paddy soil under long-term 499 fertilization practices. J Soils Sediments 8, 406-414.

500 Zinder, S.H. (1993) Physiology ecology of methanogens. In Methanogenesis ed. Ferry, J.G. 501 pp.35-80. London, UK: Chapman \& Hall. 
504 Table 1: Results of some physico-chemical analysis of samples from the the landfill cover soil and the different composts 505 understudied

\begin{tabular}{|c|c|c|c|c|c|c|}
\hline \multirow[b]{2}{*}{ Parameters } & \multirow{2}{*}{$\begin{array}{c}\text { landfill } \\
\text { Cover soil }\end{array}$} & \multicolumn{5}{|c|}{ Composts } \\
\hline & & Green waste & Biosolid & Pulp paper & Manure & Shrimp/peat \\
\hline $\mathrm{pH}$ & 8.6 & 7.7 & 7.6 & 7.6 & 7.8 & 7.0 \\
\hline Organic matter $(\%)$ & 1.14 & 22.68 & 20.01 & 21.87 & 25.27 & 20.26 \\
\hline$* \mathrm{NH}_{4}{ }^{+}$ & $<5$ & $<5$ & $<6$ & $<5$ & $<5$ & $<5$ \\
\hline$* \mathrm{NO}_{2}-\mathrm{NO}_{3}$ & 1.1 & $<0.8$ & 24.1 & 184 & $<0.8$ & 752 \\
\hline$* \mathrm{PO}_{4}{ }^{3-}$ & $<0.5$ & $<4.3$ & $<5.0$ & $<2.5$ & 848 & $<3.2$ \\
\hline *Total N & 241 & 11400 & 10700 & 9890 & 11800 & 15700 \\
\hline *Total P & 595 & 1780 & 6100 & 5080 & 10300 & 9810 \\
\hline Units & are & in & mg. $\mathrm{Kg}^{-1}$ & of & dry & weight \\
\hline
\end{tabular}


Figure legends

Fig. 1
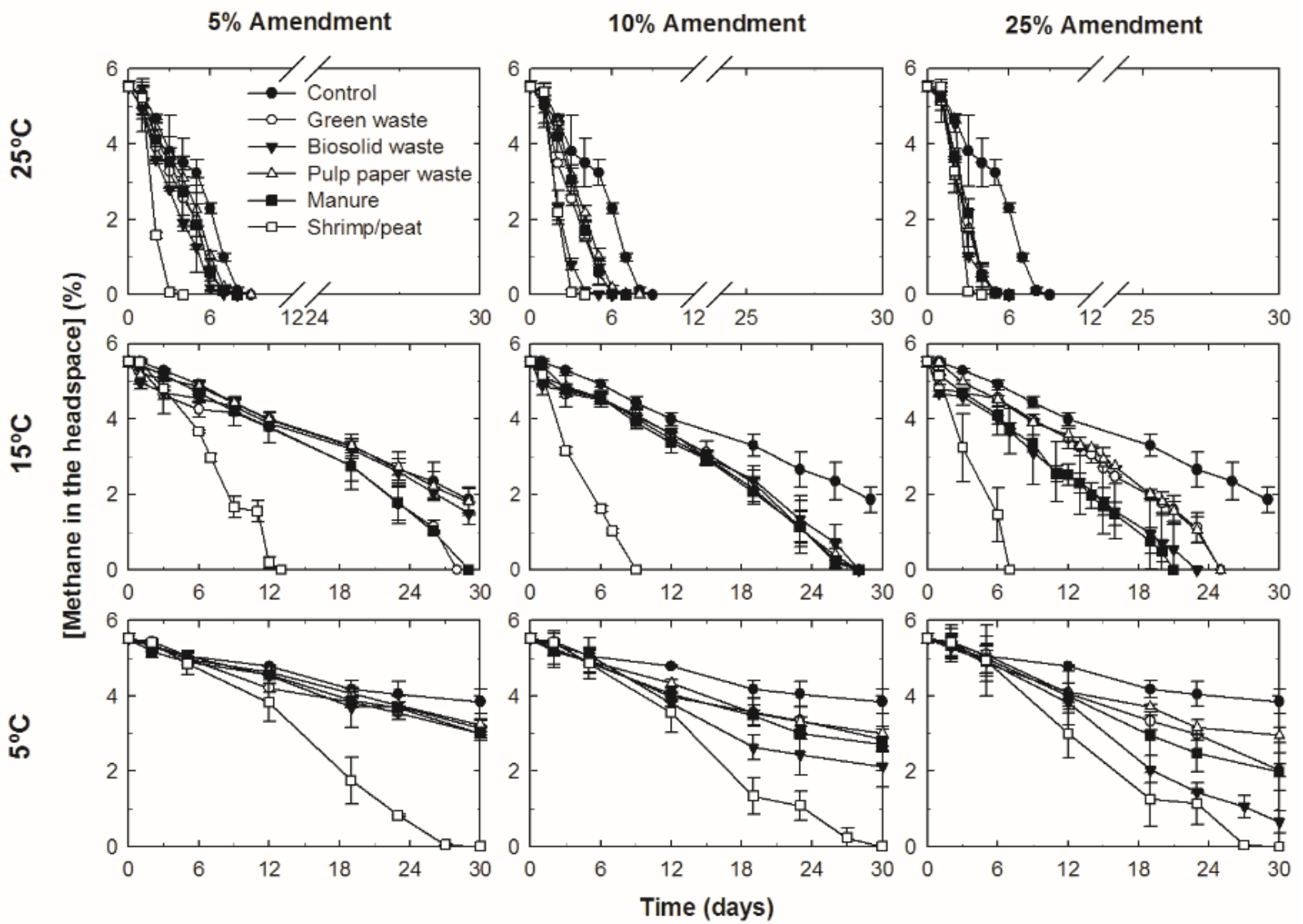

Fig. 1: Profiles of $\mathrm{CH}_{4}$ consumption over the time from our microcosms amended with variables levels of different composts and incubated under different temperatures. Data are averages of triplicates with error bars equivalent to $1 \mathrm{SD}$ 
Fig. 2

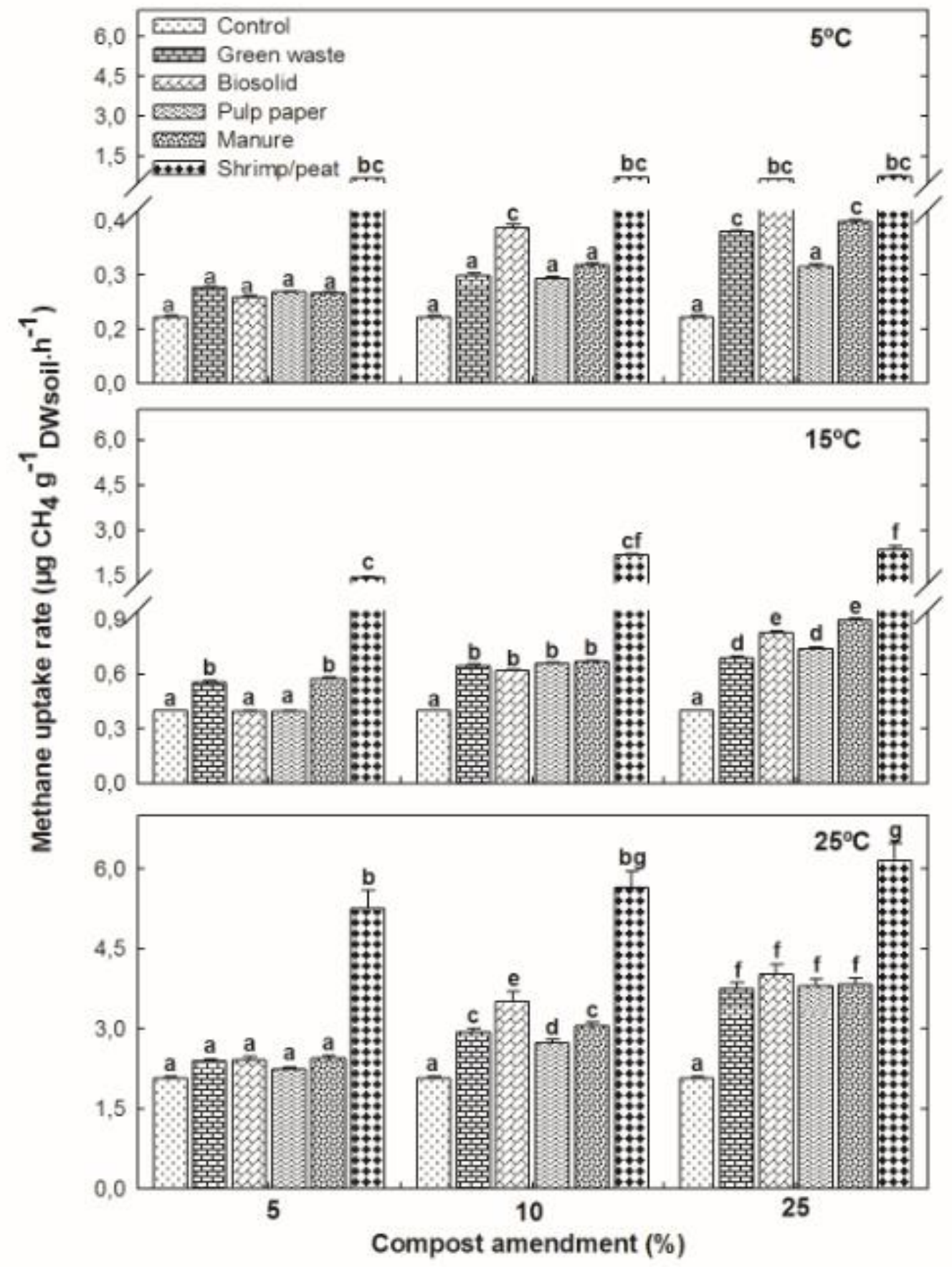

Fig. 2: Potential activity of methane oxidation rates ( \pm standard error) from our microcosms. At a given temperature, means with the same letter are not significantly different. 
Fig. 3
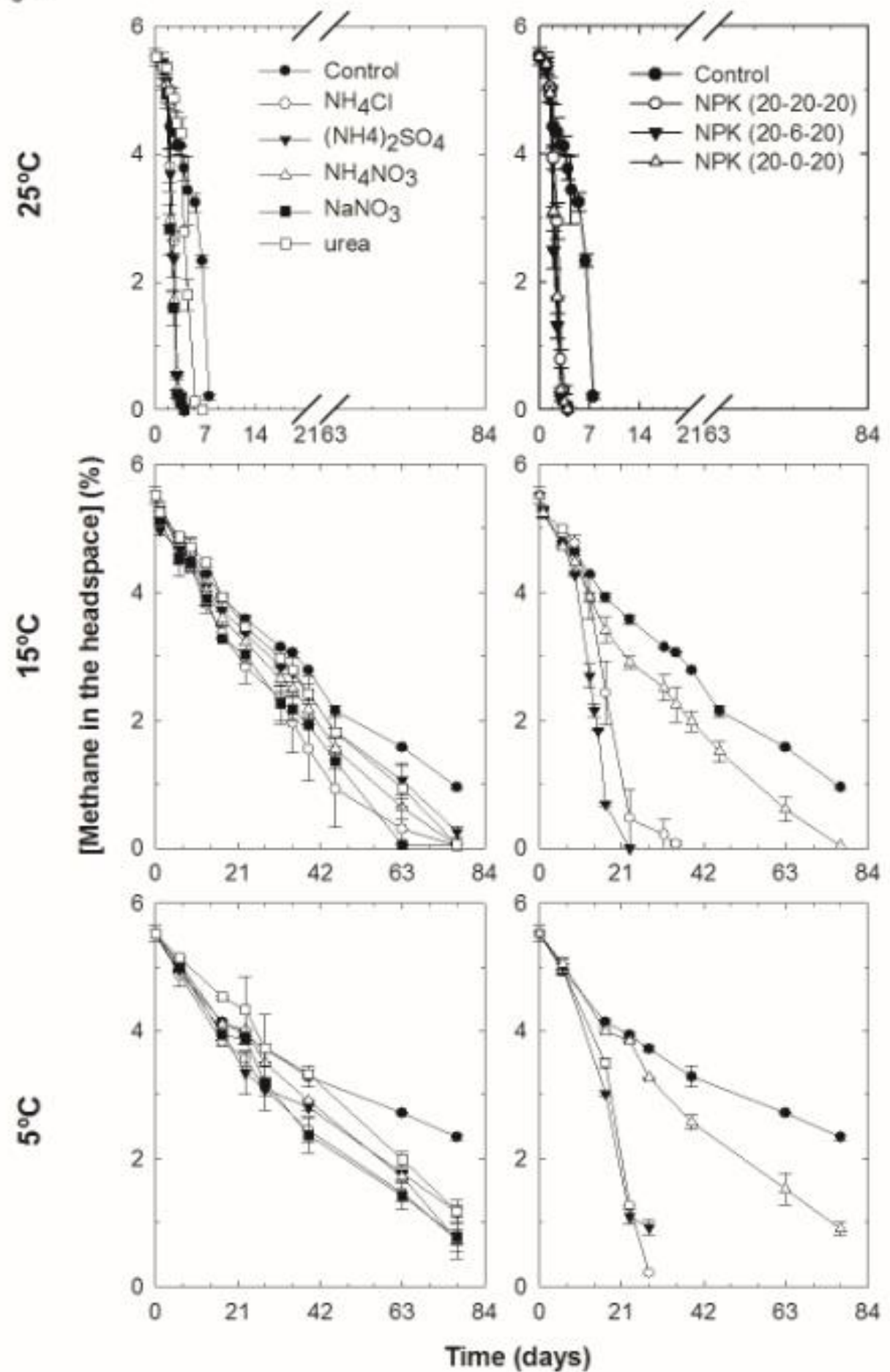

Fig. 3: Profiles of $\mathrm{CH}_{4}$ consumption over the time from our microcosms amended with different N-salts and NPK fertilizers and incubated under different temperatures. Data are averages of triplicates with error bars equivalent to $1 \mathrm{SD}$ 
Fig. 4

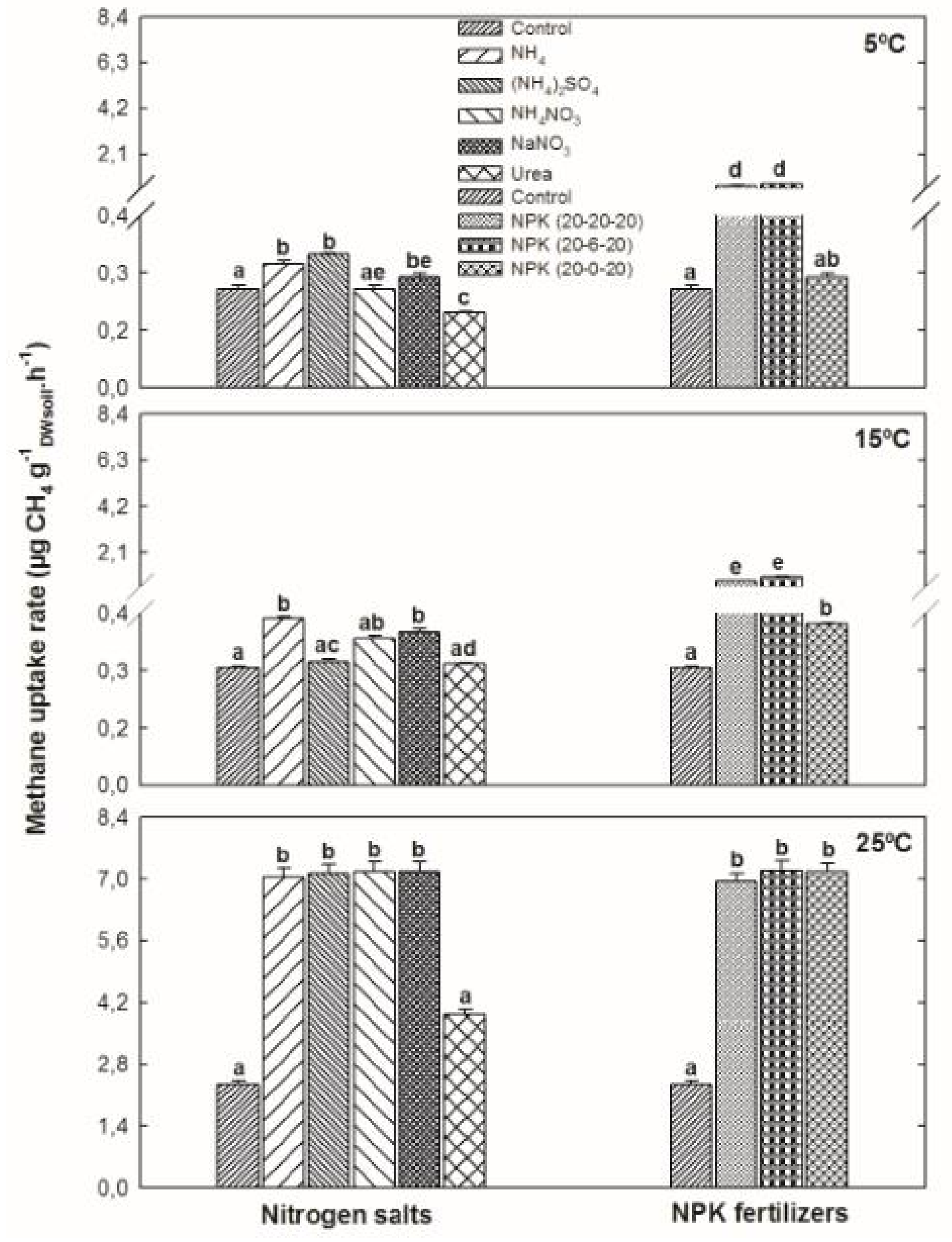

Fig. 4: Potential activity of methane oxidation rates ( \pm standard error) from our microcosms. At a given temperature, means with the same letter are not significantly different. 